\title{
Comparison of the Cytology Brush and Low Volume Lavage Techniques to Evaluate Endometrial Cytology for Diagnosing Endometritis in Chronically Infertile Mares
}

\author{
Mirela Alexandra RUS ${ }^{\star}$, Ioan Ștefan GROZA, Cristian Mihăiță CRECAN ${ }^{*}$, Zsofia DARADICS, \\ Iancu MORAR ${ }^{\times}$
}

Faculty of Veterinary Medicine, University of Agricultural Scienes and Veterinary medicine, Cluj-Napoca, Romania

*Corresponding author, e-mail: cristi_crecan@yahoo.com

${ }^{\times}$These authors have contributed equally to the work

RESEARCH ARTICLE

\begin{abstract}
Endometritis is the most common cause of subfertility and infertility in mares that leads to great economical loss. Endometrial cytology (EC) is a reliable diagnostic tool, widely used to assess the health of the reproductive tract in both humans and domestic mammals. The aim of this study was to compare two techniques for the collection of EC samples in chronically infertile mares. Ten mares aged 4 to 20 were used. In each mare, samples for EC were collected first by cytology brush $(\mathrm{CB})$ and then by low volume lavage (LVL) and stained using the Diff Quick stain. Each sample was assessed for the following parameters: background of the slides, quality and quantity of the cells obtained, number of inflammatory cells. Also, we assessed the number of operators, time and costs needed for each technique. More debris was noticed in the LVL samples, as well as a higher percentage of distorted cells. However, inflammatory cells were detected in all positive samples. Sampling by LVL required two to three operators and recovery of the lavage fluid was sometimes difficult. In conclusion, both techniques are accurate for the detection of uterine inflammation.
\end{abstract}

Keywords: brush; cytology; endometritis; low volume lavage; mare.

Received: 29 September 2020

Accepted: 19 April 2021

Published: 14 May 2021

DOI:

10.15835/buasvmcn-vm:2020.0038 published in this journal are licensed under the Creative Commons Attribution-NonCommercialNoDerivatives 4.0 International License

\section{INTRODUCTION}

Endometritis is the main cause of subfertility or infertility in the mare, leading to great economical loss in the industry. Endometritis can be grossly divided into three categories: infectious (bacterial, fungal, viral), non-infectious or chronic degenerative (endometriosis) (Hurtgen, 2006). Persistent breeding induced endometritis is a consequence of delayed uterine clearance and it can develop into infectious endometritis. A transient inflammatory response after breeding is physiological, a consequence of excess spermatozoa, extenders and microorganisms introduced in the uterine lumen, but most mares will clear the inflammation in 24-36 hours after exposure. The mechanism of clearance involves both mechanical clearancethrough uterine contractions and an innate immune response (Christoffersen and Troedsson, 2017). The gold standard for the diagnosis of endometritis in the mare is uterine biopsy (Snider et. al, 2011). However, this is currently reserved to referral centers, or laboratories equipped for the technique and is costly. Most commonly, veterinarians use bacterial cultures and cytology to diagnose endometritis. This combined technique is realiable and it can specifically differentiate between infectious and non-infectious endometritis. Empirical use of antibiotics to treat endometritis adds to the phenomenon of antibiotic resistance and might contribute to the development of fungal endometritis, which is even more challenging to treat (Beltaire et. al, 2012). Cytology is widely used to assess the health of the reproductive tract in humans, cows, bitch and mares. Several collection techniques are described, such as the cotton swab, the cytobrush, the low 
volume lavage, the aspiration technique (Liu and Troedsson, 2008). The cytobrush (CB) is recommended for the collection of samples in human medicine, for the better preservation of cancerous cells, that have to be assessed in detail (Kavak et. al, 1995). The cotton swab (CS) technique yields satisfactory result in term of inflammatory cell number, but cells are distorted. Both techniques have the major disadvantage of sampling a reduced area of the endometrium $-2-3 \mathrm{~cm}^{2} \mathrm{cranially}$ from the uterine cervical opening (Silvarua et. al, 2018). However, in the mare, endometritis seems to spread across the entire endometrium rather than being focal (Ferris, 2016). CB are produced for use in large animal and are double guarded to avoid contamination during sampling. Cytology by low volume lavage (LVL) was first used to diagnose endometritis in cows (Cheong et. al, 2012) but has been studied in mares as well (Bohn et. al, 2014). The major advantage is the increased coverage of the endometrium (Linton and Sertich, 2016) and the reduced cost, however, contamination is more likely with this single guarded technique.

Cytology is a simple, reliable method used to assess the health of the reproductive tract. It is also a straightforward technique that offers same day results. The combination of endometrial cytology smear with culture and sensitivity testing offers an accurate diagnostic tool. Interpretation of various test results can be seen in Table 1. Endometrial cytology was well described in healthy mares (Coutho, 1984), subfertile or infertile mares (Cocchiaa, 2012), post mating (Card, 2005), post-partum (Saltiel, 1987), making it a reliable diagnostic tool. In the current study, both cytology sampling techniques were reliable for the diagnostic of endometritis in chronically infertile mares. Only one LVL sample was falsely negative, out of the 20 samples analyzed, but inflammation was moderate in this case. It was previously shown that cytology is twice as reliable as culture in detecting endometritis in mares.

The aim of this study was to compare the cytology brush and low volume lavage techniques for the collection of cytology samples in chronically infertile mares. The following parameters were assessed for each sample: background of the slides, quality and quantity of the cells obtained, number of inflammatory cells. Also, we assessed the number of operators, time and costs needed for each technique.

Table 1. Cytology in conjunction with culture growth test, interpretation result

\begin{tabular}{|c|c|c|}
\hline $\begin{array}{l}\text { Culture } \\
\text { Growth }\end{array}$ & $\begin{array}{l}\text { Inflammatory } \\
\text { Cell Presence }\end{array}$ & Diagnostic Determination \\
\hline Negative & Negative & $\begin{array}{l}\text { Mare can be considered "clean" and can be bred with no further } \\
\text { diagnostic testing required }\end{array}$ \\
\hline Positive & Positive & $\begin{array}{l}\text { Mare has uterus most likely infected with the pathogen identified } \\
\text { in the culture }\end{array}$ \\
\hline Positive & Negative & $\begin{array}{c}\text { Mare is unlikely to have an infected uterus, and the sample has } \\
\text { probably been contaminated (See note on Pseudomonas } \\
\text { aeruginosa exception) }\end{array}$ \\
\hline Negative & Positive & $\begin{array}{c}\text { Mare has something irritating her uterus. In all likelihood, this is a } \\
\text { pathogen that swabbing has missed. Further diagnostic work is } \\
\text { required }\end{array}$ \\
\hline
\end{tabular}

Source https://www.equine-reproduction.com/articles/cytology.shtml

\section{MATERIALS AND METHODS}

\section{Mares}

A total of ten mares, aged 4-20 were used in this study. All mares had a history of reproductive disease (uterine collection, infertility, retained placenta, abortion). Samples were collected when mares were either in early estrus (dominant follicle $>35 \mathrm{~mm}$, uterine edema score $2 / 3$ ) or at the moment of identification of uterine collection via transrectal ultrasonography, regardless of the phase in the sexual cycle.

\section{Collection of endometrial samples}

Mares were restrained in stocks and a thorough examination of the reproductive tract was performed via transrectal ultrasonography. The cervical and uterine edema score, as well as the size and characteristics of any dominant follicle were registered (size, shape, granulosa thickness, fluid content). The base of the tail of the mare was wrapped using an elastic reusable wrap and was attached upwards in order to avoid contamination. The perineal region was scrubbed three times with clorhexidine soap (Kenoderm, Cid Lines) and was dried with disposable paper towels. An assistant started timing at this point. An operator placed a long obstetrical sleeve over his hand and arm. A double guarded cytology brush (Cytology Brush; Minitube GmbH, Germany) was passed through the vagina and cervix into the uterus. The brush was extended and gently rolled against the endometrium for 15 seconds. The brush was then retracted and gently rolled onto a pair of microscope glass slides. The slides were immediately air dried and were deposited into the specific container provided. The stopwatch was paused and time of the procedure was recorded. The same operator then passed a sterile embryo flushing 
catheter (Embryo flushing catheter $\mathrm{CH} 32$, Minitube $\mathrm{GmbH}$, Germany) 10-12 cm into the uterus without inflating the balloon of the catheter. A $60 \mathrm{ml}$ syringe previously filled with sterile saline was attached to the catheter and the fluid was infused into the uterus. After 2-3 minutes, the uterus was massaged transrectally and the fluid was recovered by gravity flow into a sterile $50 \mathrm{ml} \mathrm{Falcon} \mathrm{tube.} \mathrm{Fluid} \mathrm{was} \mathrm{sometimes} \mathrm{difficult} \mathrm{to} \mathrm{retrieve} \mathrm{and} \mathrm{an} \mathrm{additional} 60 \mathrm{ml}$ of saline had to be infused into the uterus. Timer was paused when the sample was successfully obtained. The fluid recovered was centrifuged at $500 \mathrm{G}$ for 10 minutes. The supernatant was removed and the remaining pellet was mixed. A single drop was placed onto a microscope glass slide and spread using a slide on slide manner. The paired slides were left to air dry. All cytology samples were stained using a Dip Quick Stain.

\section{Sample analysis}

Two slides per mare were analyzed under the light microscope with a x40 and x100 objective, one for each sampling technique. Five fields were recorded for each sample for the following parameters: background of the slides, quality and quantity of the cells obtained, number of inflammatory cells. Background of the slides was subjectively ranked as poor, moderate or high. Quality of the cells obtained was ranked as intact, distorted or fragmented. Number of inflammatory cells per slide was recorded. Severity of inflammation on uterine citology samples based on the number of white blood cells per high power field was ranked as no inflammation (0 WBC/hpf), mild (1-2 WBC/hpf), moderate (3-5 WBC/ hpf), severe (> $5 \mathrm{WBC} / \mathrm{hpf})$.

\section{RESULTS AND DISCUSSIONS}

\section{Background of the slides}

Background of the slides was clear in all CB samples (Figure 1). Red blood cell contamination (Figure 2 A) was present in eight out of the twenty samples analyzed, regardless of the sampling technique. However, samples obtained by LVL had a lot of debris on the background - possibly lubricating gel and mucus (Figure 2B).

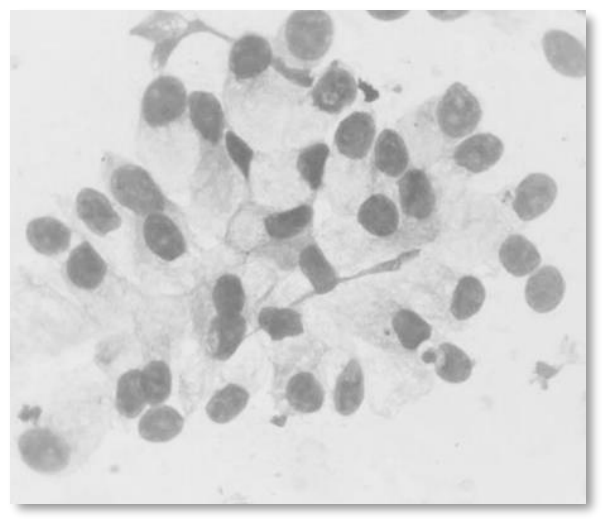

Figure 1. Well preserved endometrial cells obtained by CB in the absence of background debris

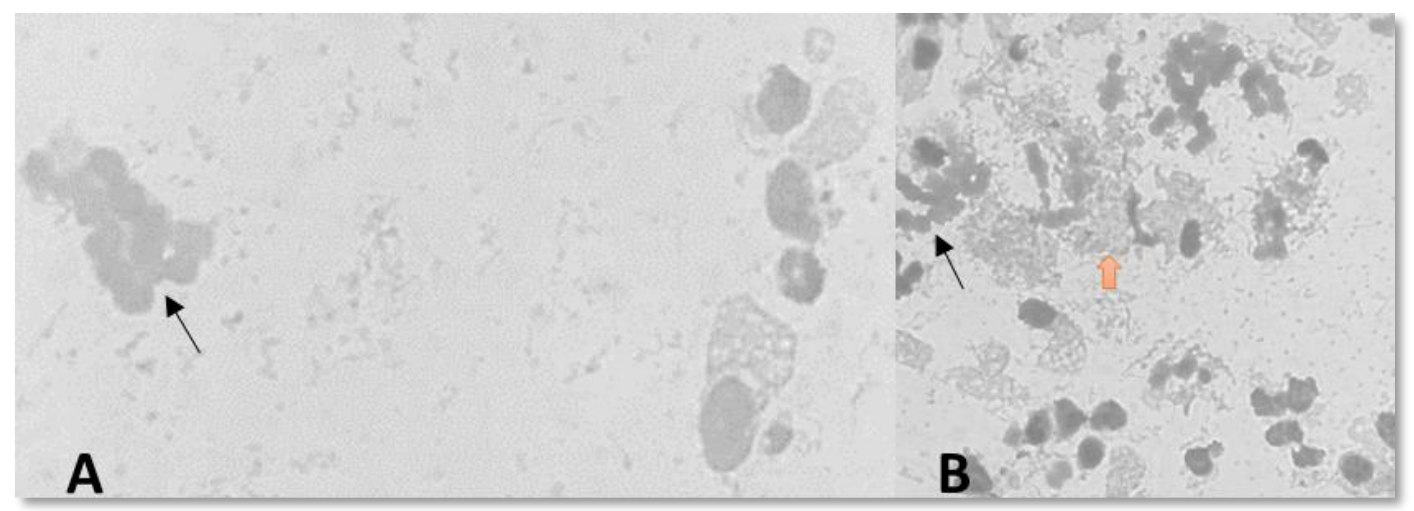

Figure 2. A Cytology sample obtained by CB 100x, B Cytology sample obtained by LVL 40x, black arrow red blood cells, red arrow debris

\section{Quality of the cells obtained}

Most cells in the CB samples were intact or slightly distorted (Figure 3A). In LVL samples cells were mostly distorted or fragmented (Figure 3B), possibly because of centrifugation. However, differentiation between neutrophils and epithelial endometrial cells was possible in all samples. 


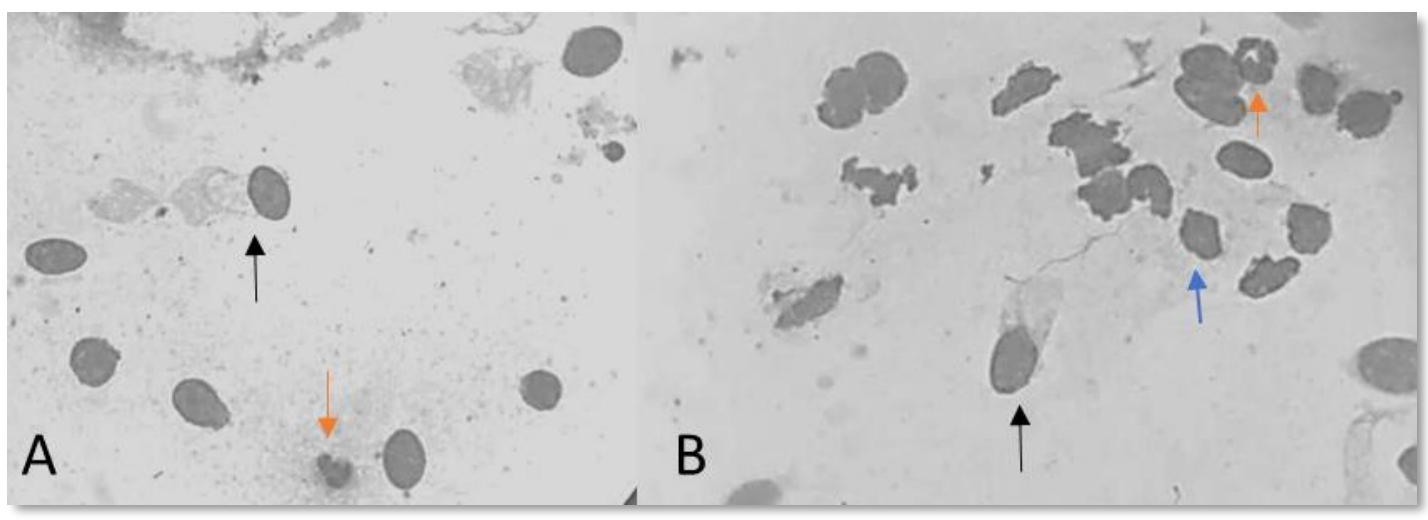

Figure. 3. A CB sample and B LVL sample: black arrow - epithelial endometrial cell; red arrow - multisegmented neutrophil; blue arrow - segmented endometrial cell.

\section{Number of cells obtained}

Number of epithelial endometrial cells obtained by both sampling techniques was similar, with a slight tendency of an increased number in CB samples. Neutrophils were easily detectable by both LVL and CB, with only one LVL sample that was not suitable for diagnosis. The sample showed a mild inflammation on the CB sample and no inflammation on the LVL sample.

\section{Sampling procedure}

Each CB sample was easily obtained by a single operator. Mean time was $5.21 \pm 0.66$. For the LVL samples time of the procedure was $12.21 \pm 3.3$ minutes, requiring 2-3 operators. In 3 of the 10 mare's recovery of the fluid was difficult, an additional $60 \mathrm{ml}$ saline had to be infused in order to obtain a sample.

Table 2. Overall results; CB citology brush, LVL low volume lavage

\begin{tabular}{|c|c|c|c|c|c|c|}
\hline Mare & $\begin{array}{l}\text { Samplin } \\
\text { g } \\
\text { techniqu } \\
\text { e }\end{array}$ & $\begin{array}{l}\text { Background } \\
\text { of the slide }\end{array}$ & Quality of cells & $\begin{array}{c}\text { Inflammatory cells/ } \\
\text { (mean }+/- \text { standard } \\
\text { deviation) }\end{array}$ & $\begin{array}{c}\text { Total number of } \\
\text { cells } \\
\text { (mean }+/- \text { standard } \\
\text { deviation) }\end{array}$ & $\begin{array}{c}\text { Time } \\
\text { (Minutes }\end{array}$ \\
\hline \multirow{2}{*}{1} & $\mathrm{CB}$ & poor & High & $7 \pm 1.4$ & $10 \pm 1.4$ & 4.2 \\
\hline & LVL & moderate & Moderate & $7 \pm 1.7$ & $9.6 \pm 1.1$ & 9.8 \\
\hline \multirow{2}{*}{2} & $\mathrm{CB}$ & poor & High & $5.4 \pm 1.8$ & $9.6 \pm 0.8$ & 5.2 \\
\hline & LVL & moderate & Poor & $4 \pm 1.7$ & $9.2 \pm 1.6$ & 16.7 \\
\hline \multirow{2}{*}{3} & $\mathrm{CB}$ & moderate & High & $1.8 \pm 0.7$ & $8.6 \pm 2.1$ & 5.5 \\
\hline & LVL & high & Moderate & $1.6 \pm 1.01$ & $8 \pm 1.4$ & 8.8 \\
\hline \multirow{2}{*}{4} & $\mathrm{CB}$ & moderate & High & $0.2 \pm 0.4$ & $10.4 \pm 1.8$ & 5.7 \\
\hline & LVL & high & Poor & 0 & $10.4 \pm 1.8$ & 9.8 \\
\hline \multirow{2}{*}{5} & $\mathrm{CB}$ & moderate & High & $5 \pm 1.4$ & $8.6 \pm 1.3$ & 6.2 \\
\hline & LVL & high & Poor & $2.6 \pm 1.2$ & $8 \pm 1.4$ & 17 \\
\hline \multirow{2}{*}{6} & $\mathrm{CB}$ & poor & High & $2.4 \pm 1.1$ & $8.2 \pm 1.7$ & 4.6 \\
\hline & LVL & moderate & Moderate & $3.4 \pm 1.4$ & $7.8 \pm 1.6$ & 15.6 \\
\hline \multirow{2}{*}{7} & $\mathrm{CB}$ & high & High & $3.2 \pm 1.3$ & $9.8 \pm 1.1$ & 4.7 \\
\hline & LVL & high & Moderate & $3 \pm 1.4$ & $9.4 \pm 1.3$ & 8 \\
\hline \multirow{2}{*}{8} & $\mathrm{CB}$ & poor & High & $3.8 \pm 1.4$ & $10.2 \pm 1.4$ & 6.2 \\
\hline & LVL & moderate & Poor & $3.6 \pm 1.8$ & $9.6 \pm 2.4$ & 9.4 \\
\hline \multirow{2}{*}{9} & $\mathrm{CB}$ & moderate & High & $0.4 \pm 0.4$ & $11.6 \pm 1.9$ & 4.5 \\
\hline & LVL & high & Poor & $0.2 \pm 0.4$ & $11.2 \pm 1.7$ & 12.3 \\
\hline \multirow{2}{*}{10} & $\mathrm{CB}$ & poor & High & $9.6 \pm 1.01$ & $10 \pm 1.6$ & 5.3 \\
\hline & LVL & moderate & Poor & $9.2 \pm 1.4$ & $9 \pm 2.6$ & 14.7 \\
\hline
\end{tabular}




\section{CONCLUSIONS}

Both sampling techniques were performed by the same operator. CB samples were easily obtained and all smears were adequate for diagnosis, with the majority of cells well preserved, as described by other several authors (Overbeck, 2011). Several LVL techniques were described, but failure to easily retrieve fluids with only $60 \mathrm{ml}$ infusion was reported with each technique (Ball, 1988; Le Blanc, 2007). In samples by LVL endometrial cells appeared distorted or lysed, but inflammatory cells were easily detectable. This technique involves more operators and is timely, but is less costly. Being a single guarded technique, it is safer to be used during estrus, to avoid uterine contamination (Aguilar, 2006).

Author Contributions: M.R. sampling and slide analysis, Ș.G. and I.M. study design, C.C. sampling, Z.D. slide analysis.

Funding Source: This research received no source of funding

\section{Acknowledgments}

The authors acknowledge the help of the team at the Equine Clinic FMV Cluj-Napoca for their help in the management of these cases.

\section{Conflicts of Interest}

The authors declare that they do not have any conflict of interest

\section{REFERENCES}

1. Aguilar J, Hanks M, Shaw DJ, Else R, Watson E. Importance of using guarded techniques for the preparation of endometrial cytology smears in mares. Theriogenology 2006; 66:423-30.

2. Ball BA, Shin SJ, Patten WH, Lein DH, Woods GL. Use of a low volume uterine flush for microbiologic and cytologic examination of the mare's endometrium. Theriogenology 1988; 29:1269-83.

3. Beltaire KA, S. H. Cheong, M. A. Coutinho da Silva. Retrospective study on equine uterine fungal isolates and antifungal susceptibility patterns (1999-2011). Equine Veterinary Journal 44, Suppl. 43 (2012) 84-87

4. Bohn AA, Ryan AF, Patrick M McCue. Comparison of equine endometrial cytology samples collected with uterine swab, uterine brush, and low-volume lavage from healthy mares. Vet Clin Pathol. 2014 Dec;43(4):594-600.

5. Card Claire. Post-breeding inflammation and endometrial cytology in mares Theriogenology Volume 64, Issue 3, August 2005, Pages 580-588

6. Cheonga SH, Nydamb DV, Galvãoa KN, Crosierb BM, Gilberta RO. Effects of diagnostic low-volume uterine lavage shortly before first service on reproductive performance, culling and milk production Theriogenology 77 (2012) 12171222 .

7. Christoffersen M, Troedsson MHT. Inflammation and fertility in the mare Reprod Dom Anim. 2017;52(Suppl. 3):14-20.

8. Cocchia N, Paciello O, Auletta L, Uccello V, Silvestro L, Mallardo K, Paraggio G, Pasolini MP. Comparison of the cytobrush, cottonswab, and low-volume uterine flush techniques to evaluate endometrial cytology for diagnosing endometritis in chronically infertile mares Theriogenology Volume 77, Issue 1, 1 January 2012, Pages 89-98

9. Coutho MA, Hughes JP. Technique and interpretation of cervical and endometrial cytology in the mare Journal of Equine Veterinary Science Volume 4, Issue 6, 1984, Pages 265-273

10. Ferris RA. Diagnostic Tools for Infectious Endometritis Vet Clin North Am Equine Pract. 2016 Dec;32(3):481-498.

11. Hurtgen JP. Pathogenesis and treatment of endometritis in the mare: A review. Theriogenology 66 (2006) 560-566

12. Kavak ZN, Eren F, Pekin S, Küllü S. A Randomized Comparison of the 3 Papanicolaou Smear Collection Methods Aust. NZ J Obsiet Gynoecol 1995; 35: 4: 446

13. LeBlanc MM, Magsig J, Stromberg AJ. Use of a low-volume uterine flush for diagnosing endometritis in chronically infertile mares. Theriogenology 2007; 68:403-12.

14. Linton JK, Sertich PL (2016). The impact of low-volume uterine lavage on endometrial biopsy classification Theriogenology Volume 86, Issue 4, 1 September 2016, Pages 1004-1007

15. Liu IKM, Troedsson MHT. The diagnosis and treatment of endometritis in the mare: yesterday and today. Theriogenology 2008 Aug;70(3):415-20.

16. Overbeck W, Witte TS, Heuwieser W. Comparison of three diagnostic methods to identify subclinical endometritis in mares. Theriogenology 2011; 75:1311-18. 
17. Saltiel A, Gutierrez A, de Buen-Llado N, Sosa C. Cervico-endometrial cytology and physiological aspects of the postpartum mare. Journal of Reproduction and fertility. Supplement, 01 Jan 1987, 35:305-309

18. Silva Rua MA, Quirino CR, Ribeiroa RB, Queiroz Carvalhoa EC, Maria de Lourdes Amaral Bernadinoa, Aylton Bartholazzi Juniora, Luisa Fernanda Cipagalta, Marcus Antônio Pessanha Barretoa. Diagnostic methods to detect uterus illnesses in mares Theriogenology Volume 114, 1 July 2018, Pages 285-292

19. Snider TA, Sepoy C, Holyoak GR. Equine endometrial biopsy reviewed: Observation, interpretation, and application of histopathologic data Theriogenology 75 (2011) 1567-1581. 